This is the author's final, peer-reviewed manuscript as accepted for publication. The publisher-formatted version may be available through the publisher's web site or your institution's library.

\title{
Characterizing prevalence and ecological impact of non- native terrestrial isopods (Isopoda, Oniscidea) in tallgrass prairie
}

Caitlin Singer, Nora M. Bello, and Bruce A. Snyder

\section{How to cite this manuscript}

If you make reference to this version of the manuscript, use the following information:

Singer, C., Bello, N. M., \& Snyder, B. A. (2012). Characterizing prevalence and ecological impact of non-native terrestrial isopods (Isopoda, Oniscidea) in tallgrass prairie. Retrieved from http://krex.ksu.edu

\section{Published Version Information}

Citation: Singer, C., Bello, N. M., \& Snyder, B. A. (2012). Characterizing prevalence and ecological impact of non-native terrestrial isopods (Isopoda, Oniscidea) in tallgrass prairie. Crustaceana, 85(12), 1499-1511.

Digital Object Identifier (DOI): doi:10.1163/15685403-00003126

Publisher's Link: http://booksandjournals.brillonline.com/content/10.1163/1568540300003126;jsessionid=1p4jfcu5em6o4.x-brill-live-01

This item was retrieved from the K-State Research Exchange (K-REx), the institutional repository of Kansas State University. K-REx is available at http://krex.ksu.edu 
2 TERRESTRIAL ISOPODS (ISOPODA, ONISCIDEA) IN TALLGRASS PRAIRIE.

3

$4 \quad \mathrm{BY}$

5

6 CAITLIN SINGER ${ }^{1^{*}}$, NORA M. BELLO ${ }^{2}$, and BRUCE A. SNYDER ${ }^{3}$

7

$8 \quad{ }^{1}$ Arizona State University, Tempe, Arizona U.S.A.

$9 \quad{ }^{2}$ Department of Statistics, Kansas State University, Manhattan, Kansas, U.S.A.

$10{ }^{3}$ Division of Biology, Kansas State University, Manhattan, Kansas, U.S.A.

11 * Corresponding author. Tel.: +1 602696 0550. E-mail address: caitlinsinger@gmail.com (C.

12 Singer). Current address: Caitlin Singer, School of Environmental and Forest Sciences, Box

13 352100, University of Washington, Seattle, WA 98195-2100.

14

15 
Isopods are terrestrial crustaceans whose role and impact in the tallgrass prairie

ecosystem remains little explored despite being rather prevalent non-native inhabitants. To better understand this role, we conducted two related studies. The first was a rapid survey of isopods in experimental treatments at Konza Prairie LTER site to investigate the diversity and relative abundance of isopod species present. Of the four species known in Kansas thus far, all nonnative, Armadillidium vulgare was the most abundantly found, accounting for $93 \%$ of individuals found. Armadillidium nasatum, Cylisticus convexus, and Porcellionides pruinosus were also found and we report the first record of Porcellio laevis in the State of Kansas. Survey results showed no evidence for a relationship between isopod abundance and fire frequency or grazing treatment.

The second experiment was a food preference study to explore granivory in non-native isopods and characterize their seed predator behavior on native plants. Individual isopods were placed in Petri dishes with food options including leaf litter and seeds from one of 15 species; dishes were then incubated for 6-12 days and preference was assessed based on pre- and posttrial weights of the feed and individual isopod. Isopods showed a significant preference for leaves compared to seeds in nine of the 15 seed species evaluated; no evidence for leaf-vs.-seed preference was apparent in the remaining six seed species. However, in all cases, isopods did consume some amount of seeds even when leaf litter was present. Taken together, the relatively low abundance of non-native terrestrial isopods and their lack of apparent preference for native plant seeds suggest that isopods are unlikely to pose considerable threat to tallgrass prairie ecosystems. More extensive research, including a preference study with greater representation of 
seed species and a quantitative survey throughout the year, would be needed to further characterize the ecological role of isopods in the tallgrass prairie.

\section{INTRODUCTION}

Isopods of a broad spectrum of sizes and shapes can be found in both aquatic and terrestrial ecosystems (Brusca \& Wilson, 1991). Terrestrial isopods, the focus of our experiments, are very adaptable and can be found in almost any environment provided there is sufficient moisture and food. They typically have minimal food constraints due to their generalist diet and opportunistic feeding (Causey, 1952; Hassall \& Rushton, 1982; Saska, 2008), though they do seem to have a preference for microbially colonized decaying organic materials, including plant litter (Paoletti \& Hassall, 1999; Ihnen \& Zimmer, 2008). Isopods are historically widespread and abundant across North America, despite being non-native fauna, and have been described to aggregate in high densities, reaching as many as thousands per $\mathrm{m}^{2}$ (Causey, 1952; Paoletti \& Hassall, 1999) . Their plethoric numbers and synanthropic nature (Jass \& Klausmeier, 2000) suggest that they are adaptable to most environments, with a recognized role in the ecosystem as an accelerator of plant matter decomposition (Hassall et al., 1987; Zimmer, 2002). This is likely achieved by mandibular fragmenting of leaves, which in turn executes chemical decomposition in the environment by stimulating the growth of microbes (Warburg, 1993; Zimmer et al., 2003).

Little is known about terrestrial isopod ecology and distribution in Kansas, especially in the highly fragmented and threatened tallgrass prairie ecosystem (Cully et al., 2003; Reed, 2004). Diversity and distribution of isopod species in Kansas has also received little attention; species known in Kansas prior to this study were Armadillidium nasatum Brandt 1833, Armadillidium vulgare (Latreille 1804), $\underline{\text { Cylisticus convexus (DeGeer 1778) and Porcellionides pruinosus }}$ 
64 areas, but also within relatively undisturbed prairie habitats (e.g., logs, stones, vegetation), so that encounters of isopods with plant seeds are quite plausible (Saska, 2008).

Seed predation can have a considerable impact on plant demography, potentially

67 affecting population growth, dispersal and population structure (Saska, 2008). While several species of marine isopods are known to consume seeds (Fishman \& Orth, 1996; Holbrook et al., 2000; Orth et al., 2006, 2007), terrestrial species have only recently been established as granivorous in laboratory experiments (Saska, 2008). Seed dispersal and establishment are

71 known to be important events in plant populations (Benson \& Hartnett, 2006), with select

72 advantages being movement away from predation near parent plant and suitable germination 73 microsites (Collins \& Uno, 1985). Prairie insects can have a detrimental effect on seed dispersal and plant reproductive success (Evans et al., 1989); if terrestrial isopods were found to also act as seed predators, they could plausibly have a similarly detrimental effect on plant reproduction.

76 Therefore, depending on their relative abundance, distribution, and food preference, non-native

77 isopod species present in Kansas could pose a threat to the conservation of native plants in this

78 ecosystem which has already been highly impacted by land-use change. Two studies were

79 undertaken to address the potential conservation implications of terrestrial isopod presence. The

80 specific objectives of the studies were: to investigate the diversity and relative abundance of non-

81 native isopod species in the tallgrass prairie and to characterize their seed predator behavior on

82 native plants. Preliminary sampling during summer 2010 indicated that the most commonly

83 found isopod was Armadillidium vulgare; our objective was to test $\underline{\text { A. vulgare's preference for }}$ 84 leaf litter versus native seed species of Konza Prairie. 
88 in partnership by The Nature Conservancy and Kansas State University. It is located in the Flint

89 Hills of northeastern Kansas, within the largest area of unplowed tallgrass prairie in North

90 America, retaining much of its native uniqueness. It is used as a field research station by Kansas

91 State University Division of Biology, providing opportunities for study of tallgrass prairie

92 ecosystems (Freeman \& Hulbert, 1985). Konza Prairie is divided into watershed-scale treatments

93 including watersheds that are either ungrazed or grazed by ungulates (American bison, Bison

94 bison (Linnaeus 1758)), in combination with burn frequencies of 1-, 2-, 4- and 20-year intervals

95 (Towne, 2002).

96 Survey

97 A rapid survey approach was employed across watersheds within a short period of time.

98 This was primarily done to limit the effects of Kansas' highly variable weather on survey results.

99 Sampling occurred during the week of 6 to 12 March 2011 on a total of 16 watersheds, so that

100 each combination of prescribed fire frequency and grazing treatment was represented by 2

101 watersheds. Three sampling sites were selected a priori in each chosen watershed, thus yielding a

102 total of 48 samples.

In order to maximize likelihood of isopod presence, the collectors made an effort to

104 stratify the samples within each watershed by several factors: distance from disturbed areas (e.g., 105 roads dividing watersheds), type of vegetation, and position on the landscape. Specimen

106 collection was by hand and restricted to an approximate $5 \mathrm{~m}$ x $5 \mathrm{~m}$ area and 30 person-minutes

107 (Snyder et al., 2006). Once collected, specimens were placed in a vial with soil and leaves to be 108 taken back to the lab for identification. 
111 Experiments were conducted during the summer of 2010 at Kansas State University (trials 1-3)

112 and the fall of 2010 at Arizona State University (trial 4). Seeds and leaf litter were collected from

113 Konza Prairie and Kansas State University campus. Petri dishes (100 x 15mm) were set up so

114 that each contained one isopod, leaf (trials 1-3) or grass (trial 4) litter, and one native plant seed 115 species. Each Petri dish was considered an experimental unit. This resulted in five experimental

116 units per seed species in trials 1-3, and four experimental units per seed species in trial 4. Dishes

117 were misted daily with water. Individual isopods (live biomass), litter, plant seeds and fecal

118 pellets (air-dried) were weighed before and after each trial. Seeds and leaves were provided in

119 standard and relatively large amounts to prevent confounding due to limited food availability, 120 independent of trial duration. As consumption rates were unknown, trial durations were

121 relatively short but varied between trials as we sought the ideal duration.

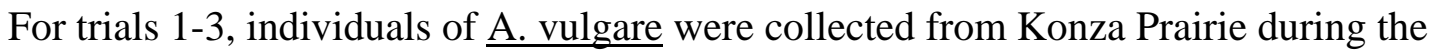
summer of 2010 and data collection was conducted during 23 June - 27 July 2010. Trials 1 and 2

124 lasted 6 and 12 days respectively, with both using the seeds of five native Kansas plant species:

125 Desmanthus illinoensis (Michaux) MacMillan (Illinois Bundleflower), Psoralidium tenuiflorum

126 (Pursh) Rydb. (Scurfy pea), Helianthus maximiliani Schrader (Maximilian Sunflower), $\underline{\text { Solidago }}$

127 rigida (Linnaeus) (Rigid Goldenrod) and Sorghastrum nutans (Linnaeus) Nash (Indiangrass). The 128 third trial lasted nine days and used the seeds of five native Kansas plant species: Zigadenus 129 paniculatus (Nutt.) S. Watson (Death Camas), Tripsacum dactyloides (Linnaeus) Linnaeus 130 (Gamagrass), Elymus canadensis Linnaeus (Canada Wildrye), Oenothera macrocarpa Nutt. 131 (Missouri Evening Primrose) and Asclepias viridiflora Raf. (Green Milkweed). Time constraints disallowed for the entire study to be completed during the primary 133 investigator's 10-week Research Experiences of Undergraduates (REU) project during the 134 summer of 2010 at Kansas State University; thus a further trial in the food preference study (trial 
135

136

137

138

139

140

141

142

143

144

145

146

147

148

149

150

151

152

153

154

155

156

157

158

4) was conducted during fall of 2010 at the primary author's home institution of Arizona State University. For trial 4, materials and specimens were mailed from the original collection site to Arizona State University.

Data collection for trial 4 was conducted during 14 October - 10 November 2010. Isopods were collected during a single day from Kansas State University campus, approximately

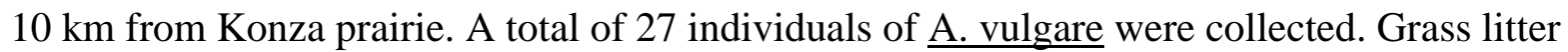
was collected from a mowed fire guard in the Konza Prairie Biological Station headquarters area during the spring of 2010, allowed to air dry, and stored until the initiation of the experiment. Seed decay was attempted for the purpose of enhancing consumption given isopods’ well described preference for decaying matter (Paoletti \& Hassall, 1999; Ihnen \& Zimmer, 2008). Seed decay was initially induced for 4 days for the first three seed species listed below, with the remaining four seed species added after this pre-testing was determined unnecessary, for a total of 20 days for the first three seed species, and 16 for the remaining four (see next paragraph). Seeds of each species were moistened and allowed to sit in a Petri dish in a warm location. This was intended to facilitate decomposition, but appeared ineffective, as no visible evidence of decay could be found.

Trial 4 lasted nine days and evaluated seeds from the following seven native Kansas plant species: Zizia aurea (Linnaeus) W.D.J. Koch (Golden Zizia), Desmanthus illinoensis (Illinois Bundleflower), Sporobolus heterolepis (A. Gray) A. Gray (Prairie dropseed), Silphium

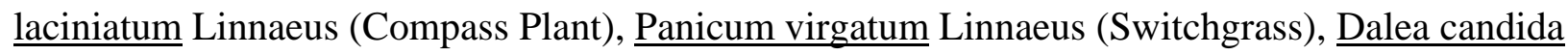
Michx. ex Willd. (White Prairie Clover), and Elymus canadensis (Canada Wildrye). Statistical Analysis

For survey data, a generalized linear mixed model was fitted to count of isopods recorded on each survey sample. The response was fitted using a Poisson distribution with a log link 
function. The linear predictor included the fixed effects of grazing and prescribed fire frequency

160

161

162 163 164 165 166

179 Criteria. treatments. The interaction between grazing and prescribed fire frequency was evaluated as a fixed effect but was excluded from the final model based on evidence for model overspecification. The random effect of watershed nested within grazing and prescribed fire frequency treatment was also specified to recognize technical replication in the design and to appropriately recognize experimental units.

The experimental setup for food preference Trials 1, 2 and 3 was similar; thus, we analyzed their data in a joint analysis. A general linear mixed model was fitted to the response variable "Feed consumption" defined as the difference between weight of initial feed offered and weight of refuse feed (measured in grams) for Trials 1, 2 and 3. The linear predictor of the model used for analysis included the fixed effects of feed source (seed or leaf), seed species and their 2way interaction, along with the covariates initial feed weight and initial isopod bodyweight. Additional interactions were evaluated but were not included in the final model based on nonsignificant P-values, maximum-likelihood-based model fit criteria and an attempt to prevent model overparameterization. A random effect of isopod nested within seed species for each trial was fitted to the model to recognize the appropriate experimental unit for seed species and the blocking factor for feed source. A random effect of trial was evaluated as a potential blocking factor. However, the corresponding variance component converged to zero and thus the random trial effect was dropped from the model. Heterogeneous residual variances as a function of trial were fitted in the model, as granted by improved model fit assessed using Bayesian Information 
182 183 184 185 186 187 188 189 190 191 192 193 194 195 196

variable "Feed consumption" as described previously for data from trials 1-3. We note that only 7 seed species were evaluated in this trial.

Statistical models were fitted to the survey and food preference data using the GLIMMIX and MIXED procedures of SAS (Version 9.2, SAS Institute, Cary, NC), respectively. For general linear models, studentized residual plots were evaluated and model assumptions were considered to be appropriately met. Estimated standard errors were bias corrected using Kenward Roger's or Morel's Sandwich estimator, as implemented by SAS for general and generalized linear mixed models. Also, degrees of freedom were estimated using Kenward Roger's approximation.

Results are presented as estimated least square means and corresponding standard errors. Pairwise comparisons of interest were conducted using Tukey-Kramer's or Bonferroni's adjustment, as appropriate, to avoid inflation of Type I error rate.

\section{RESULTS}

Isopod diversity, relative abundance and distribution at Konza Prairie

Our survey of Konza Prairie found only 15 individuals of two species, Armadillidium

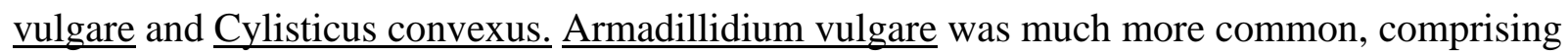
14 of 15 specimens (93\%), and was found under shrubs, in leaf litter, moist soil, ungulate fecal matter and under rocks.

Isopod specimens were collected from 6 out of the 16 watersheds (table I). Most notably, no isopods were recovered from watersheds with 20-year fire frequency intervals and only 1 and 2 individuals were collected in 2- and 4-year fire frequency treatments, respectively. However, we found no evidence of significant differences between grazing treatments $(P=0.90)$ or prescribed fire frequencies $(\mathrm{P}=0.25$ ) in the count of isopod specimens. 

the Kansas State University campus yielded Armadillidium nasatum, $\underline{\text { Porcellionides pruinosus }}$ and Porcellio laevis Latreille 1804. Our identification of Porcellio laevis constitutes a new state

208 record for Kansas and was found at Konza Prairie, within watershed N1B under aged bison fecal 209 matter.

\section{Food preference study}

For Trials 1-3, the joint analysis showed evidence for a significant interaction between

212 seed species and feed source $(\mathrm{P}<0.0001)$ on feed consumption. In particular, the question of

213 interest related to differences in consumption between feed sources (i.e., leaves vs. seeds) within

214 each seed species. Significant differences in feed consumption between sources (fig. 1) were

215 apparent for the following native plant species: Tripsacum dactyloides (Gamagrass), Oenothera

216 macrocarpa (Missouri Evening Primrose), Helianthus maximiliani (Maximilian Sunflower), and

217 Sorghastrum nutans (Indiangrass). For these native plant species, seed consumption was

218 decreased compared to leaf consumption. As a side note, we point out that gamagrass exhibited a 219 negative estimate for consumption due to minimal consumption combined with the growth of 220 fungi and bacteria, resulting in a positive change in mass.

222 positively associated with feed consumption $(\mathrm{P}<0.0001)$, whereby every 1 gram increase in feed 223 offered increased feed consumption by an estimated $0.15 \pm 0.02$ grams for a given isopod. After 224 adjusting for initial feed consumption, there was no evidence for any association between initial 225 isopod bodyweight and feed consumption $(\mathrm{P}=0.84)$.

227 Elymus canadensis (Canada Wildrye) were excluded from analysis due to the high isopod 228 mortality rate. In this trial, a main effect of feed source on feed consumption was identified $(\mathrm{P}=$ 
229 0.0112). For the five remaining seed species considered in this experiment, isopods appeared to 230 consume more leaves than seeds (fig. 2). There was no evidence of interaction between seed 231 species and feed source $(\mathrm{P}=0.19)$ on feed consumption. Also, there was no evidence for an 232 association between initial isopod bodyweight and feed consumption $(\mathrm{P}=0.62)$ nor for any 233 association between initial feed availability and feed consumption $(\mathrm{P}=0.82)$.

\section{DISCUSSION}

Due to widespread land-use change, the tallgrass prairie ecosystem is threatened and highly fragmented (Cully et al., 2003). Thus the conservation of native plant species is important to the maintenance of this ecosystem's distinctive character and ecosystem functioning. Invasive 239 plant and animal species are a major threat; insects, in particular those known as seed predators, 240 pose a special challenge by limiting seed dispersal (Evans et al., 1989). Due to the realization of 241 a similar niche, isopods may fulfill a comparable role to seed predating insects, potentially by

242 harming reproductive or dispersal abilities of native plant species. Past studies have recognized 243 the role isopods have as decomposers in the tallgrass prairie ecosystem (Hassall et al., 1987; 244 Zimmer, 2002) and have explored food preferences (Dudgeon et al, 1990; Rushton \& Hassall, 245 1983). Granivory behavior of isopods has been described (Saska, 2008; Honek et al., 2009;

246 Farmer \& Dubugnon, 2009) and determined to be facultative (Koprdova et al., 2010). Moreover, 247 isopod granivory behavior seems to be driven by seed abundance, nutrition and accessibility 248 (Saska, 2008). If isopods are abundant and widespread seed predators, they could prove to be a 249 threat to native plants of the tallgrass prairie. 
253 depauperate at Konza Prairie. It was initially hypothesized that more isopods would be found in

254 less frequently burned watersheds because of the protection and food provided by the higher

255 abundance of plant detritus. We did not find evidence to support this claim; potential

256 explanations include food quality, favorability of drier environments and/or open habitats. These

257 preliminary data suggest that more work is needed to assess the effects of prescribed fire,

258 grazing, and other land use changes on terrestrial isopods. In particular, other survey techniques

259 should be considered, such as pitfall traps to complement manual searches as their combination

260 may enhance effectiveness of the search (Snyder et al., 2006).

261 Food preference studies

This study showed a preference against consuming seeds relative to plant litter for nine of

263 the 15 seed species present; no evidence for differential source preference was apparent for the

264 other six native plant species. This supports the observations and conclusions of Saska (2008),

265 including granivory in terrestrial isopods despite the presence of litter, which is possibly

266 indicative of non-starvation based granivory, but may also be due to factors such as size, climate,

267 season, and decomposition state of feed source (Hassall \& Moss, 2011; Szekeres et al., 2011).

268 This lack of evidence for associations between feed consumption and initial isopod bodyweight

269 further link the two studies. We therefore hypothesize a difference in seed palatability,

270 compatibility, and preference for consumption amongst different seed species.

Easily available litter-colonizing microbiota becomes a valuable resource to isopods

272 when population density is driven by food quality (Zimmer \& Topp, 2000; White, 1978). Access

273 to highly nitrogenous foods is known to be limited for saprophagous, soil-dwelling animals

274 (Rushton \& Hassall, 1983; White, 1978). This available supply of a vital nutrient such as

275 nitrogen may therefore affect feeding preference (Zimmer \& Topp, 2000), with consumption due 
to the nutritional content of the microorganisms residing on the different leaf species, rather than the nutrition of the leaf species themselves (Zimmer \& Topp, 1997). Chemical composition of the food source as well as amount of colonization by microbes may both influence their consumption by isopods. Indeed, chemical composition of leaf litter has been addressed when looking at food source utilization by sympatric woodlice species Porcellio scaber Latreille 1804 and Oniscus asellus (Linnaeus 1758), with results showing a better performance associated with a lower litter C:N ratio, higher $\mathrm{pH}$ levels, and lower levels of tannins and other phenolics (Zimmer \& Topp, 1997).

Future food preference experiments should take into account the morphology (Pulliam \& Brand, 1975) and chemical composition (Zimmer \& Topp, 2000) of seeds consumed, offer an assortment of leaf species and shapes (Dudgeon et al., 1990), and test for litter quality through factors such as microbiota colonization, pH levels, and nutrient ratios (Zimmer \& Topp, 1997, 2000). While this study examined seeds that were accessible during the time frame of the study, there are hundreds of species of vascular plants (Freeman \& Hulbert, 1985) on Konza Prairie that could provide food for isopods. Species where seed-based reproduction is important or species whose seeds are used in restoration would be high priority for future studies.

\section{Conclusions}

Conservation of native plants is critical for protecting the remaining fragments of North American tallgrass prairie. Large populations of granivorous invertebrates could negatively affect the survival rates of native plants. However, it appears that isopods are at low densities regardless of the fire regimes evaluated herein, namely historical, more frequent (as is used for cattle management across much of the Flint Hills region), and less frequent (fire suppression near

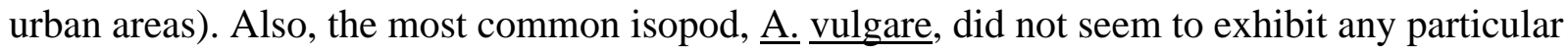


300 preference for native plant seeds. Taken together, this evidence suggest that isopods may pose

301 little, if any, threat to the native plants of Konza Prairie, as representative of tallgrass prairie

302 systems.

303

304

\section{ACKNOWLEDGEMENTS}

The authors would like to acknowledge the assistance of Arizona State University, Dr.

306 Ron Rutowski, Dr. James Elser, Dr. Ari Jumpponen, Konza Prairie Biological Station, Konza

307 Prairie LTER, Adam Skibbe, Dan Carter, Ben VanderWeide, and members of the Kansas State

308 University Summer 2010 Biology and Engineering REUs. This work was funded by the Biology

309 REU (NSF DBI-0851835) and SUROP programs at Kansas State University. We thank

310 anonymous reviewers for constructive comments.

311

\section{LITERATURE CITED}

313 BEnSON, E.J. \& D.C. HARTNETT, 2006. The role of seed and vegetative reproduction in plant 314 recruitment and demography in tallgrass prairie. Plant Ecology, 187: 163-177.

315 BRUSCA, R.C. \& G.D.F. WiLsOn, 1991. A phylogenetic analysis of the Isopoda with some

316 classifactory recommendations. Memoirs of the Queensland Museum. 31: 143-204.

317 CAusey, D., 1952. The terrestrial Isopoda of Arkansas. Proceedings of the Arkansas Academy of $318 \quad$ Science, 5: 25-30.

319 Collins, S. \& G.E. UnO, 1985. Seed predation, seed dispersal, and disturbance in grasslands: a 320 comment. American Naturalist, 125: 866-872.

321 Cully, A., J. Cully JR. \& R. Hiebert, 2003. Invasion of exotic plant species in tallgrass prairie 322 fragments. Conservation Biology, 17: 990-998. 
DudGeON, D., H.H.T. MA \& P.K.S LAM, 1990. Differential palatability of leaf litter to four sympatric isopods in a Hong Kong forest. Oecologia, 84: 398-403.

EvAns, E.C. SMITH \& R. GENDRON, 1989. Timing of reproduction in a prairie legume: seasonal impacts of insects consuming flowers and seeds. Oecologia, 78: 220-230.

FARMER, E.E. \& L. DUBUGNON, 2009. Detritivorous crustaceans become herbivores on jasmonate-deficient plants. Proceedings of the National Academy of Sciences of the United States of America, 106: 935-940.

FISHMAN, J.R. \& R.J. ORTH, 1996. Effects of predation on Zostera marina L. seed abundance. Journal of Experimental Marine Biology and Ecology, 198: 11-26.

Freeman, C. \& L. Hulbert, 1985. An annotated list of the vascular flora of Konza Prairie Research Natural Area, Kansas. Transactions of the Kansas Academy of Science, 88: 84-115.

HASSALL, M. \& S.P. RuSHTON, 1982. The role of coprophagy in feeding strategies of terrestrial isopods, Oecologia, 53: 374-381.

Hassall, M., J.G. TuRnER \& M.W.R. RANDS, 1987. Effect of terrestrial isopods on the decomposition of woodland leaf litter. Oecologia, 72: 597-604.

HASSALL, M., A. Moss. 2011. Effects of simulated climate change on ecology and behaviour of terrestrial isopods. Proceedings of the 8th International Symposium of Terrestrial Isopod Biology. Bled, Slovenia, Ljubljana: pp. 85-86.

Holbrook, S.J., D.C. Reed, K. Hansen \& C.A. Blanchette, 2000. Spatial and temporal patterns of predation on seeds of the surfgrass Phyllospadix torreyi. Marine Biology, 136: 739-747.

HoneK, A., Z. Martinkova, P. SASKA \& S. Koprdova, 2009. Role of post-dispersal seed and seedling predation in establishment of dandelion (Taraxacum agg.) plants. Agriculture, Ecosystems and Environment, 134: 126-135. 
IHNEN, K. \& M. ZIMMER, 2008. Selective consumption and digestion of litter microbes

by Porcellio scaber (Isopoda: Oniscidea). Pedobiologia, 51: 335-342.

JASS, J. \& B. KLAUSMEIER, 2000. Endemics and immigrants: North American terrestrial isopods (Isopoda, Oniscidea) north of Mexico. Crustaceana, 73: 771-799.

JASS, J. \& B. KLAUSMEIER, 2001. Terrestrial isopod (Crustacea: Isopoda) atlas for Canada, Alaska and the contiguous United States. Milwaukee Public Museum Contributions in Biology and Geology, 95: 1-105.

Koprdova, S., P. SAska, A. HoneK \& Z. Martinkova, 2010. Seed consumption by millipedes. Pedobiologia, 54: 31-36.

ORTH, R.J., G.A. KENDRICK \& S.R. MARION, 2006. Predation on Posidonia australis seeds in seagrass habitats of Rottnest Island, Western Australia: patterns and predators. Marine Ecology Progress Series, 313: 105-114.

ORTH, R.J., G.A. KENDRICK \& S.R. MARION, 2007. Posidonia australis seed predation in seagrass habitats of Two Peoples Bay, Western Australia. Aquatic Botany, 86: 83-85.

PaOletti, M. \& M. Hassall, 1999. Woodlice (Isopoda:Oniscidea): their potential for assessing sustainability and use as bioindicators. Agriculture, Ecosystems and Environment, 74: 157165.

Pulliam, R. \& M.R. BRAnd, 1975. The Production and Utilization of Seeds in Plains Grassland of Southeastern Arizona. Ecology, 56: 1158-1166.

REED, A.W., 2004. Granivory in the prairie of Central North America. Dissertation, Kansas State University.

RushtON, S.P. \& M. HASSALL, 1983. Food and feeding rates of the terrestrial isopod Armadillidium vulgare (Latreille). Oecologia, 57: 415-419.

SASKA, P., 2008. Granivory in terrestrial isopods. Ecological Entomology, 33: 742-747. 
371 Snyder, B.A., M.L. Draney \& P. Sierwald, 2006. Development of an optimal sampling

372 protocol for millipedes (Diplopoda). Journal of Insect Conservation, 10: 277-288.

373 SZEKERES, S., D. FÜLÖP, P. SZABÓ, E. HoRnUnG \& F. VILISICS. 2011. Intra-population differences

374 in litter consumption of Porcellio scaber Latreille, 1804. In: Zidar, P. \& J. Strus (szerk.)

375 Proceedings of the 8th International Symposium of Terrestrial Isopod Biology. Bled,

$376 \quad$ Slovenia, Ljubljana: pp. 143-144.

377 Towne, E.G., 2002. Vascular Plants of Konza Prairie Biological Station: An Annotated

378 Checklist of Species in a Kansas Tallgrass Prairie. Sida, 20: 269-294.

379 WArBurg, M.R., 1993. Evolutionary Biology of Land Isopods: 1-159. (Springer, New York).

380 WHITE, T.C.R., 1978. Importance of a relative shortage of food in animal ecology. Oecologia,

$381 \quad 33: 71-86$.

382 ZIMMER, M. \& W. TOPP, 1997. Does leaf litter quality influence population parameters of the common woodlouse, Porcellio scaber (Crustacea:Isopoda)? Biology and Fertility of Soils, 24:

385 ZIMMER, M. \& W. TOPP, 2000. Species-specific utilization of food sources by sympatric $386 \quad$ woodlice (Isopoda: Oniscidea). Journal of Animal Ecology, 69: 1071-1082.

387 ZIMMER, M., 2002. Nutrition in terrestrial isopods (Isopoda: Oniscidea): an evolutionary388 ecological approach. Biological Reviews of the Cambridge Philosophical Society, 77: 455389493.

ZIMMER, M., G. KAUTZ \& W. TOPP, 2003. Leaf litter-colonizing microbiota: supplementary food 391 source or indicator of food quality for Porcellio scaber (Isopoda: Oniscidea)? European 392 Journal of Soil Biology, 39: 209-216. 
397 Figure 1: Feed consumption in trials 1-3 of the food preference study, presented as least square 398 mean estimates \pm estimated standard errors (SE). Asterisks indicate native plant species for 399 which seed consumption was significantly reduced relative to leaf consumption $(\mathrm{P}<0.05)$. IB = 400 Desmanthus illinoensis (Illinois Bundleflower), $\mathrm{SP}=\underline{\text { Psoralidium tenuiflorum (Scurfy pea), MS }}$

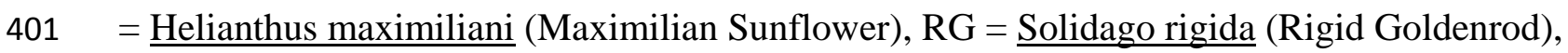
$402 \mathrm{SOR}=\underline{\text { Sorghastrum nutans }}$ (Indiangrass), $\mathrm{DC}=\underline{\text { Zigadenus paniculatus }}$ (Death Camas), GAMA $403=\underline{\text { Tripsacum dactyloides }}$ (Gamagrass), $\mathrm{CR}=\underline{\text { Elymus canadensis }}$ (Canada Wildrye), $\mathrm{MEP}=$

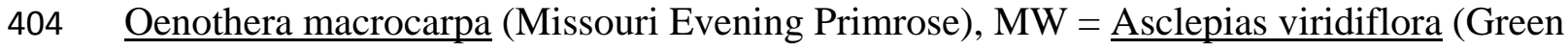
405 Milkweed).

406

407 Figure 2: Feed consumption in trial 4 of the food preference study, presented as least square 408 mean estimates \pm estimated standard errors (SE). $I B=\underline{\text { Desmanthus illinoensis }}$ (Illinois

409 Bundleflower), $\mathrm{PV}=\underline{\text { Panicum virgatum }}$ (Switchgrass), $\mathrm{SH}=\underline{\text { Sporobolus heterolepis }}$ (Prairie 410 dropseed), SL = Silphium laciniatum (Compass Plant), and WPC = $\underline{\text { Dalea candida }}$ (White Prairie 411 Clover). Species Zizia aurea (Golden Zizia) and Elymus canadensis (Canada Wildrye) were 412 excluded. 
Figure 1:

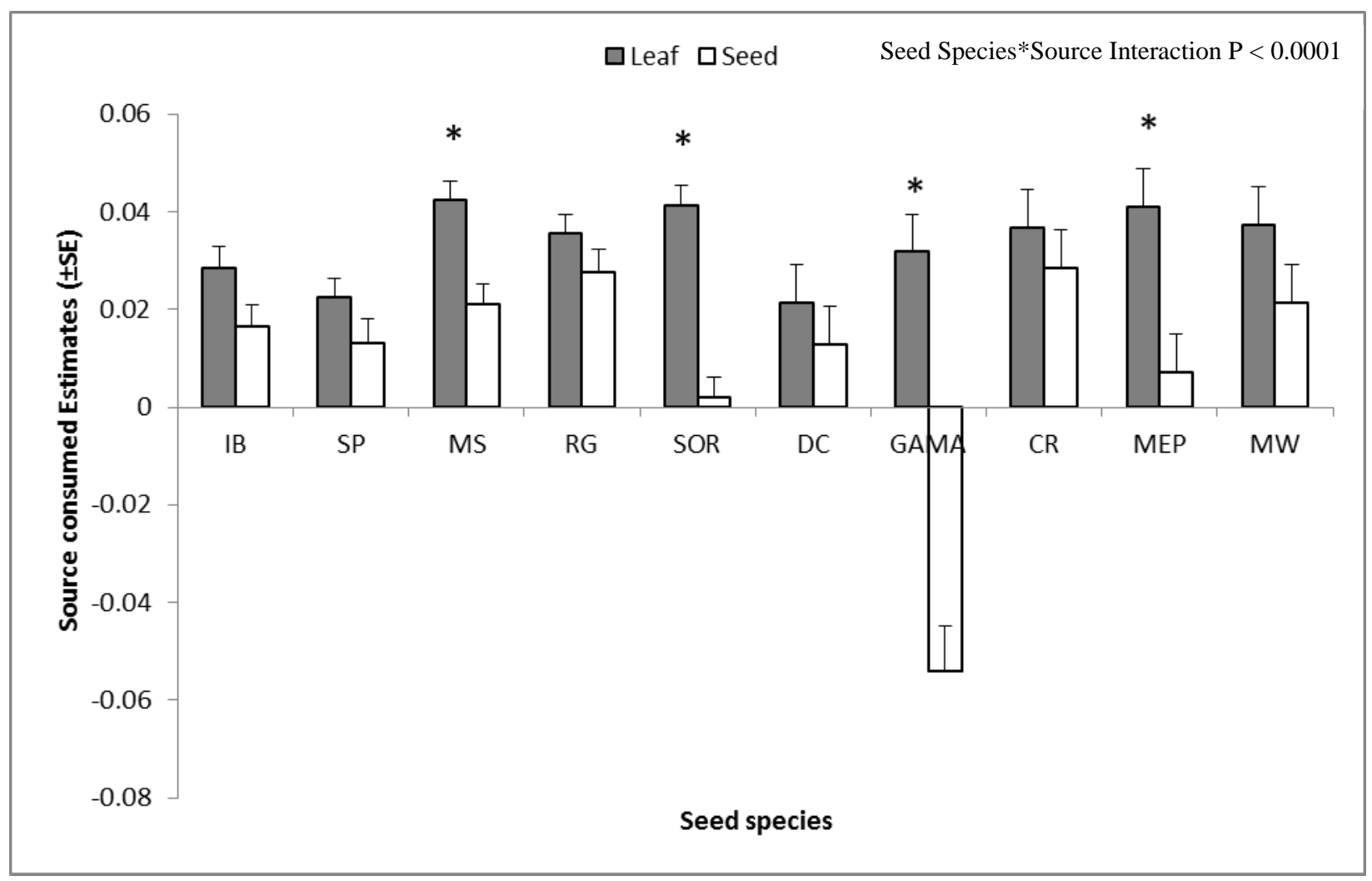

417

418 
Figure 2:

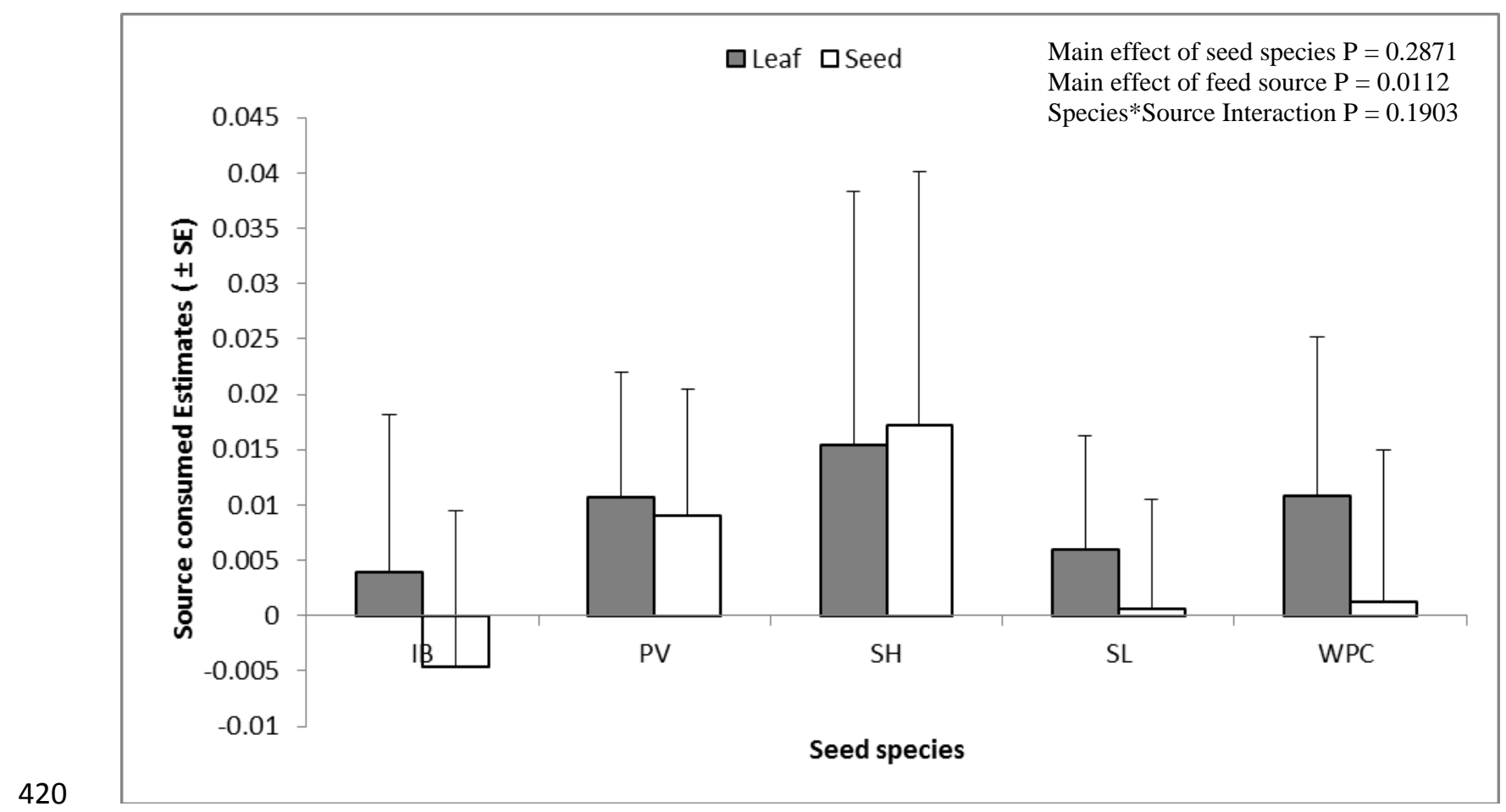

421

422 
423 Table I: Number of isopod individuals and species found in each fire and grazing regime.

424

425

Main effect of grazing treatment $\mathrm{P}=0.90$

Main effect of fire frequency $\mathrm{P}=0.25$

\begin{tabular}{|c|c|c|c|}
\hline $\begin{array}{c}\text { Fire } \\
\text { Frequency } \\
\text { (years) }\end{array}$ & Grazing Treatment & $\begin{array}{c}\text { Individuals } \\
\text { Found }\end{array}$ & Species Found \\
\hline 1 & Grazed & 5 & $\underline{\text { Armadillidium vulgare }}$ \\
\hline 2 & Ungrazed & 7 & $\underline{\text { Armadillidium vulgare }}$ \\
\hline 4 & Grazed & 1 & Cylisticus convexus \\
& Ungrazed & 0 & Armadillidium vulgare \\
\hline 20 & Grazed & 1 & Armadillidium vulgare \\
\hline & Ungrazed & 1 & -- \\
\hline
\end{tabular}

426 